F. YOSHIMURA, M. SASAKI, I. HATTORI, K. KOMATSU, M. SAKAI, K. TANINO,

\title{
Synthesis of Zoanthamine
}

\section{Key words}

\section{zoanthamine}

intramolecular Diels-Alder reaction

photooxidation

conjugate addition<smiles>CC1CC=CC(=O)C1</smiles><smiles>CCOCCOC(C)=C(C)C</smiles>

A<smiles></smiles>

c

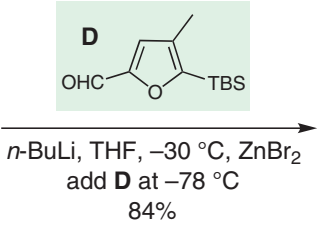<smiles>Cc1cc2oc1C(=CCO)C(=O)OCC2</smiles>

copper<smiles>COC1(C)CC(=O)CC2C3CC(C)CC(OC(C)=O)C3CC(=O)C21C</smiles>

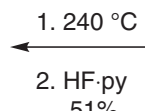<smiles>C=C(/C=C(\C)C1CC(C)CC(O)C1CC(=O)/C=C(\C)C(C)=O)O[Sn]</smiles>
G OTBS

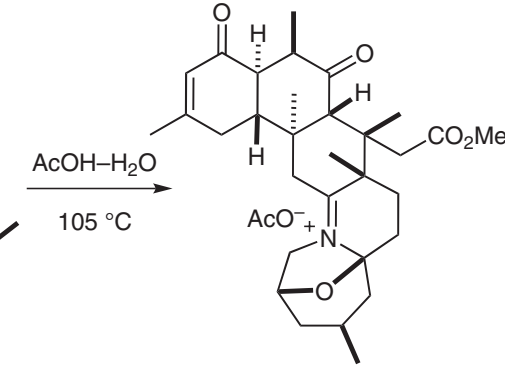
J

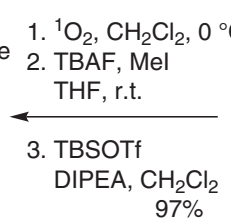

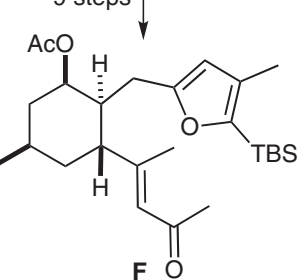

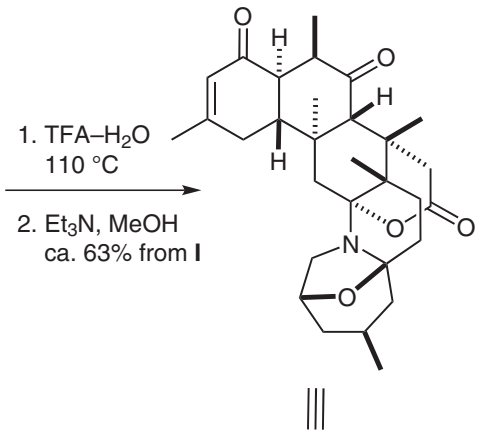

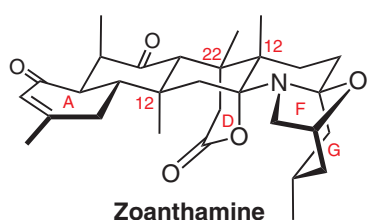

Zoanthamine

favored exo-TS leading to $\mathbf{H}$

Significance: Zoanthamine is a marine metabolite that inhibits phorbol myristate-induced inflammation. It is also an analgesic that inhibits human platelet aggregation. Major challenges in this synthesis were (1) construction of the trans-antitrans perhydrophenanthrene $\mathrm{ABC}$ ring system; (2) construction of the three ring $\mathrm{C}$ quaternary centers at C9, C12 and C22; (3) construction of the two quaternary aminal centers.
Comment: The trans-anti-trans ring system in intermediate $\mathbf{H}$ was constructed by an exo-selective intramolecular Diels-Alder reaction. Nine of the eleven stereogenic centers were created by diastereoselective reactions starting from $(R)-5$ methyl-2-cyclohexenone $(\mathbf{A})$ and $(R)$-citronellal. The synthesis required 43 steps and proceeded in $2.2 \%$ overall yield (average $91 \%$ yield per step).

SYNFACTS Contributors: Philip Kocienski 